\title{
Training access, reciprocity, and expected retirement age
}

Citation for published version (APA):

Montizaan, R. M., de Grip, A., \& Fouarge, D. (2015). Training access, reciprocity, and expected retirement age. ROA. ROA Research Memoranda No. 001 https://doi.org/10.26481/umaror.2015001

Document status and date:

Published: 01/01/2015

DOI:

10.26481/umaror.2015001

Document Version:

Publisher's PDF, also known as Version of record

\section{Please check the document version of this publication:}

- A submitted manuscript is the version of the article upon submission and before peer-review. There can be important differences between the submitted version and the official published version of record.

People interested in the research are advised to contact the author for the final version of the publication, or visit the DOI to the publisher's website.

- The final author version and the galley proof are versions of the publication after peer review.

- The final published version features the final layout of the paper including the volume, issue and page numbers.

Link to publication

\footnotetext{
General rights rights.

- You may freely distribute the URL identifying the publication in the public portal. please follow below link for the End User Agreement:

www.umlib.nl/taverne-license

Take down policy

If you believe that this document breaches copyright please contact us at:

repository@maastrichtuniversity.nl

providing details and we will investigate your claim.
}

Copyright and moral rights for the publications made accessible in the public portal are retained by the authors and/or other copyright owners and it is a condition of accessing publications that users recognise and abide by the legal requirements associated with these

- Users may download and print one copy of any publication from the public portal for the purpose of private study or research.

- You may not further distribute the material or use it for any profit-making activity or commercial gain

If the publication is distributed under the terms of Article $25 \mathrm{fa}$ of the Dutch Copyright Act, indicated by the "Taverne" license above, 


\section{Training access, reciprocity, and expected retirement age}

Raymond Montizaan

Andries de Grip

Didier Fouarge

\section{ROA Research Memorandum}

ROA-RM-2015/1

Researchcentrum voor Onderwijs en Arbeidsmarkt | ROA

Research Centre for Education and the Labour Market | ROA 


\title{
Training access, reciprocity, and expected retirement age
}

\author{
Raymond Montizaan \\ Andries de Grip \\ Didier Fouarge
}

ROA-RM-2015/1*

February 2015

Research Centre for Education and the Labour Market

Maastricht University

P.O. Box 616, 6200 MD Maastricht, The Netherlands

$\mathrm{T}+31433883647 \mathrm{~F}+31433884914$

secretary-roa-sbe@maastrichtuniversity.nl

www.roa.nl

\footnotetext{
* The ROA Research Memorandum Series was created in order to make research results available for discussion, before those results are submitted for publication in journals.
} 


\section{Abstract}

\section{Training access, reciprocity, and expected retirement age**}

This paper investigates whether employers can induce employees to postpone retirement by offering access to training courses that maintain job proficiency. We use unique, matched employer-employee surveys for the Dutch public sector, which include detailed information on a wide range of HR practices applied in the organization, as well as the expected retirement age of its employees. We find that training policies, as reported by employers, are significantly positively related to employee expected retirement age, irrespective of whether employees actually participate in training. We show that this positive relationship is driven by employees' positive reciprocal inclinations, indicating that provision of training may serve as a tool to motivate older employees in their job and consequently to retire later. The provision of training access may therefore complement existing pension reforms in many industrialized countries that aim to increase labor-force participation of older workers. Robustness analyses indicate that the relationship between offering training access and expected age of retirement is unlikely to be driven by reverse causality, self-selection, or the presence of other organizational characteristics.

JEL classification: J24, J31, 12

Keywords: trainng access, reciprocity and retirement

$\begin{array}{ll}\begin{array}{l}\text { Raymond Montizaan } \\ \text { Maastricht University }\end{array} & \begin{array}{l}\text { Andries de Grip } \\ \text { Maastricht University } \\ \text { ROA }\end{array} \\ \begin{array}{l}\text { R.O. Box } 616 \\ \text { NL-6200 MD Maastricht }\end{array} & \text { NL-6200 MD Maastricht } \\ \text { The Netherlands } & \text { The Netherlands } \\ \text { r.montizaan@maastrichtuniversity.nl } & \text { a.degrip@maastrichtuniversity.nl } \\ \text { and Netspar and IZA } & \text { and Netspar and IZA } \\ \text { Didier Fouarge } & \\ \text { Maastricht University } & \\ \text { ROA } & \\ \text { P.O. Box616 } & \\ \text { NL-6200 MD Maastricht } & \\ \text { The Netherlands } & \\ \text { d.fouarge@maastrichtuniversity.nI } & \\ \text { and Netspar } & \end{array}$

** We thank Eric Bonsang, Lei Delsen, Arjan Non, Veronica Frisancho, Tom Stolp, and participants of the Netspar theme conference "Human Capital and Aging," Maastricht (October, 2013), the IAB "Labor Market Prospects of Older Workers International Conference' Nürnberg (October 2014), and the DUHR seminar Maastricht (September, 2014) for their useful comments. 


\section{Introduction}

Many industrialized countries are simultaneously confronted with population aging and an ongoing transition of their economy to a knowledge-based economy (see, e.g., Katz and Autor, 1999; Hanushek and Woessmann, 2010). These trends represent a major challenge to employees, employers, and policy makers (Galasso and Profeta, 2004) and will increase the urgency to encourage older employees to remain employable (Daveri and Maliranta, 2006). A major complication, however, is that the recent pension reforms in many industrialized countries tend to demotivate workers (see, e.g., De Grip et al., 2012; Montizaan et al., 2012; Montizaan and Vendrik, 2014). Therefore, it is important to study which policies can best influence workers' employability.

Providing training access may be a promising policy instrument to improve the job motivation, competencies, and productivity of older workers who have to continue working to a later age due to pension system reforms. Several empirical studies found that training participation is instrumental in compensating for skills depreciation and maintaining employability (Bishop, 1997; Groot and Maassen van den Brink, 2000; De Grip and Van Loo, 2002; Picchio and Van Ours, 2013). Moreover, various empirical studies have shown that training participation is positively associated with job effort, productivity, and wages (Bartel, 1994, 1995; Barrett and O'Connell, 2001; Conti, 2005; Dearden et al., 2006; Zwick, 2006; Fersterer et al., 2008; Konings and Vanormelingen, 2009; De Grip and Sauermann, 2012). ${ }^{1}$

1. However, human capital theory also predicts that employers have fewer incentives to invest in older employees, because the period in which the benefits of training can be reaped decreases with age (Ben Porath, 1967; Neumann and Weis, 1995). Older workers may also endure higher psychological costs of training due to a lower capacity to learn new skills. These lower investments in human capital can therefore decrease employee retirement age (Green, 1993). Various studies showed that training incidence decreases with age. Moreover, Bassanini et al. (2005) and Fouarge and Schils (2009) found that training participation of older workers is lower in countries with more generous early pension systems, while Montizaan et al. (2010) showed that the retrenchment of pension rights leads to higher training participation among older workers in large organizations. Similarly, Brunello and Comi (2013) showed that policies that increase the retirement age are effective in increasing training participation by senior workers. 
There are few empirical studies, however, that directly analyzed the relationship between training and retirement (e.g., Stenberg et al., 2012; Picchio and Van Ours, 2013). These studies found mixed results. Stenberg et al. (2012) found no relationship between training and retirement, while Picchio and Van Ours (2013) found that firm-provided training significantly increases future employment prospects of older workers. Stenberg et al. (2012) and Picchio and Van Ours (2013), however, have in common that they measure the effects of actual training participation of individual employees on their retirement behavior. These studies see retirement primarily as an individual labor supply decision, but neglect the role of firms' training provision. This is surprising, since the impact of employer policies on employee retirement decisions is well established (e.g., Johnson and Neumark, 1996; Dorn and Sousa-Poza, 2010). One of the few studies to consider the role of employers is Herrbach et al. (2009), who used survey data on the availability of particular types of training from a sample of late-career managers to estimate the effect of training availability on the timing of retirement. Consistent with the results of Picchio and Van Ours (2013), these authors found that training access significantly increases the retirement age. ${ }^{2}$

In this study, we investigate whether training access in organizations, as reported by the employer, is related to the expected retirement age of their employees. We draw on employerprovided measures of provision of training access. We build on two linked employer-employee surveys conducted in April 2012 in the Dutch public and privatized sector. ${ }^{3}$ The employer survey is specifically designed to collect detailed information on organizations' HR practices targeted at older workers, and includes several measures of the extent to which the employer stimulates training

2. Their training measure, however, is based on a survey question, which asks late-career managers to rate the availability of training opportunities adapted to their current needs, implying that in cases where managers report having no training opportunities relevant to their current needs, it is impossible to determine whether they have no training opportunities, or whether they have no training needs.

3. Although the data set, because of its cross-sectional nature, does not allow us to fully control for biases due to unobserved heterogeneity at the individual level, combining employer and employee data at least reduces the likelihood of reverse causality, as it is less likely that retirement preferences of individual employees will affect the presence of training policies within their organizations. In Section 3.3, we provide robustness analyses that address the issue of reverse causality in more detail. 
participation. ${ }^{4}$ The employee survey elicits respondents' expected retirement age, in addition to detailed questions on employees' job tasks, actual training participation, and personality traits.

We show that employees in organizations that provide more training access to older workers expect to retire at a significantly later age than those who are employed in organizations that provide little or no access to training. A one-standard deviation increase in the provision of training access is associated with approximately 1.1 to 3.0 months later retirement. When we compare the size of this correlation to the impact of major pension reforms on expected retirement age, it becomes clear that training access is of great economic importance. For example, De Grip et al. (2013) find that an announced increase in the Dutch statutory retirement age by one year increased the expected retirement age by only 3.9 months. Interestingly, for other HR practices targeted at older workers but that are unrelated to training, we find no significant relationship with employee retirement age expectations. Robustness analyses further indicate that the relationship between training access and expected retirement age is unlikely to be driven by reverse causality, self-selection, or organizational characteristics.

This study builds on the existing literature in two ways. First, rather than analyzing the effects of actual training participation on retirement behavior, we complement previous retirement studies by integrating matched employee and employer data on employer-provided training access and employee retirement expectations into one framework. Since we measure training access in an employer survey, it is less likely to be confounded by employee characteristics and skill needs than in studies that measure training access in employee surveys. The richness of our data further allows us to test the robustness of our findings to alternative model specifications (such as the inclusion of firm-specific random effects), as well as to the inclusion of additional control variables that, among others, capture differences in the financial situation of firms, the role of other HR practices in firms that offer training, and self-selection of highly motivated workers into organizations with ample training facilities.

4. Note that these measures capture firm characteristics, and do not necessarily mean that the respondents employed in the firms that offer training access actually participate in training. 
Second, we provide insight into potential mechanisms that drive the positive relation between having training access and expected retirement age. We consider whether the relationship between training access and retirement expectations is driven by employees' actual training participation but find no evidence for this. Employees in organizations that offer training access to all their older workers indeed participate in training more often and expect to retire later. However, the positive relationship between training access and expected retirement age remains when we control for workers' training participation. This indicates that access to training may have positive effects on the timing of retirement, even if employees do not actually participate in training.

We show that the relationship between training access and the expected retirement age is driven by employees' positively reciprocal inclinations. Accordingly, we contribute to the growing literature that predicts that reciprocity is a key driver of human motivation and labor market outcomes (Akerlof, 1982; Pereira et al., 2006; Bowles, 2008). Numerous empirical studies have used a giftexchange framework to stress the importance of reciprocity, and find that positively reciprocal employees increase their efforts above the required level when treated generously by their employers (e.g., Fehr et al., 1993; Fehr et al., 1998; Charness, 2000 Brown et al., 2004; Bellemare and Shearer, 2009; Cohn et al., 2009; Kube et al., 2012). The role of reciprocal behavior by employees in relation to the human capital investments by their employer, however, is a relatively unexplored topic. A notable exception is Leuven et al. (2005), who applied a gift-exchange framework to explain why employers are willing to provide both firm-specific and general training to their employees. Their argument is similar to that of the efficiency-wage literature, which predicts that higher effort levels can be achieved when employers pay wages above the market-clearing wage (Akerlof, 1982). Training improves employees' individual knowledge, skills, and productivity. When employers are willing to offer opportunities for general and firm-specific training, employees may perceive this offer as good treatment that signals attention and recognition by the employer, to which they positively reciprocate by providing greater effort and higher commitment (Barrett and O'Connell, 2001). Employees may alternatively show their appreciation by signaling that they are willing to postpone their retirement. Delaying retirement can be beneficial to employers, as this allows them to reap the 
benefits of investments in the human capital of their current employees for a longer period. Our findings thus show that the provision of training access not only improves the skills and productivity of employees, but it also has major positive behavioral consequences on the willingness to delay retirement. Providing training access could therefore be a useful alternative policy instrument to increase labor-force participation by older workers, and may even help to partially counter the negative effects that pension reforms have on employee motivation.

The remainder of this paper proceeds as follows. Section 2 describes the data, provides descriptive statistics, and sets forth information on the representativeness of the estimation sample. Section 3 presents the results, and Section 4 concludes.

\section{Data}

\subsection{Data description}

We use matched employer-employee survey data on the Dutch public and privatized sectors, collected in April 2012 (the ROA Public Sector Survey 2012), to examine the relationship between provision of organizational training access reported by employers and the expected retirement age of their employees. The survey data are matched to administrative data from the Dutch pension fund for public sector employees $(\mathrm{ABP})$, which contains information on the number of contribution years to the pension fund, the number of working hours, and the specific industry sector in which the respondents are employed: public administration, education, or privatized organizations (such as public transport companies and oil and gas exploration companies).

The employee survey data were collected in two stages. In the first stage, a representative, randomly selected sample of 57,350 public sector employees born between 1946 and 1975 was contacted in the spring of 2012 by ABP via regular post. They were asked to provide their e-mail addresses for an online survey on retirement-related issues. In the second stage, in the first week of April 2012, we sent an e-mail containing the link to our web-based survey to the 12,600 employees who had provided their e-mail addresses. This employee survey contained detailed questions on 
retirement expectations, sources of income after retirement, job characteristics, and a battery of questions to measure employee personality. Some 6,200 individuals completed the questionnaire. ${ }^{5}$

For the employer survey, we sent an e-mail in April 2012 to all 2,500 employers in the public and privatized sectors with a link to the web-based survey. ${ }^{6}$ This employer survey included detailed questions on training and HR practices. The e-mail was sent to HR-advisors, HR-managers and managing directors who are responsible for HR practices and all retirement related issues within their organizations. The survey was answered by 783 employers.

In total, we were able to match the survey data of 1,337 employees to the answers of 363 employers. Because of non-response to questions that are relevant to our analyses, we base our estimation sample on 845 employees matched to 284 employers. Although the largest industry sectors tend to be over-represented and the smaller sectors tend to be under-represented, the overall distribution in our estimation sample of workers across sectors looks rather similar to that in the representative sample of workers (see Appendix A). Moreover, the employees matched to their employers are similar to those for whom no match is available. ${ }^{7}$

5. Our data set does not include information on actual retirement behavior. To our knowledge, however, there exists no data set that provides matched information on training access as reported by employers, actual training behavior, as well as actual retirement behavior of employees.

6. The e-mail addresses were provided by ABP, which has detailed contact information for each employer, due to its role as the public sector's pension fund.

7. T-statistics for the differences in organizational characteristics between employers with and without a match to their employees are presented in Table B3, in Appendix B. The table shows that most differences in the variable means between both groups are statistically insignificant. Employers whose answers can be matched to the answers of their employee, however, have a higher percentage of highly educated workers than those without a match. Further, they report more often that their organization is financially sound, but also report a higher likelihood that their organization must cut expenses in the coming five years. 


\subsection{Measurement and descriptive statistics}

\subsubsection{Main variables}

Our main interest lies in investigating how employees' retirement expectations are related to the training access provided by their employer. Earlier studies that used survey questions to directly measure expectations show that this measure may be a good predictor for actual retirement behavior (Keane and Runkle, 1990; Das et al., 1999; Dominitz, 2001; Stephens Jr., 2004; Hurd, 2009). ${ }^{8}$ Retirement expectations are measured by the question At what age do you expect to retire?, to which respondents could reply in full years using pre-coded answers ranging from 55 to 70 years-old.

Our measure of training access is derived from employers' answers to a set of questions on 17 HR practices focused on older workers. Employers were asked the following question: To what extent does your organization apply the following HR-instruments that are specifically targeted towards older employees? For the 17 specific HR practices displayed in Appendix A, employers could answer on a five-point Likert scale ranging from 1 Not applied to any older employee to 5 Applied to all older employees. ${ }^{9}$ A factor analysis revealed that these 17 specific HR practices can be grouped into five main factors: 1) Training access (e.g., extra courses or training for older workers); 2) Task adaptation (e.g., allocate older workers to tasks they are good at); 3) Financial incentives (e.g., demotion); 4) Working hours policies (e.g., reduction of working hours for older workers); and 5) Retirement policies (e.g., phased retirement). We then standardized these measures of HR practices to mean 0 and standard deviation 1. Training access is the key variable of interest in our analysis, and other HR

8. Few studies have focused on retirement and pension expectations. These studies show that expectations are strongly related to retirement decisions, but also provide mixed evidence on the ability of workers to assess financial decisions (Duflo and Saez, 2003; Benitez-Silva and Dwyer, 2005; Chan and Stevens, 2008; Alessie et al., 2011; Liebman and Luttmer, 2011; Van Rooij et al., 2011, 2012). Montizaan et al. (2010), however, provide evidence that Dutch public sector employees are well informed about their pension rights and the implications of the changes in the pension system in the past decades for their pension benefits and timing of retirement.

9. The 17 items belonging to this survey question are presented in Table A1 in Appendix A. 
practices serve as control variables measuring the impact of additional HR policies targeted toward older employees. ${ }^{10}$

\subsubsection{Basic control variables}

We gathered detailed information in the employee survey on workers' actual training participation, willingness to train, personal characteristics and personality traits, job engagement, and main job tasks, which we use as control variables in our analysis. ${ }^{11}$ Actual training participation is measured by a dummy variable indicating whether the respondents participated in any training course in the preceding year, and by the number of training courses in which an employee participated. ${ }^{12}$ For the last training course completed, it is known whether it was aimed at general or firm-specific skills, and whether the employer initiated this training. This is based on two survey questions: To what extent do you agree with the following proposition about the last training course you concluded: The knowledge received during this training is transferable to organizations outside the branch in which you are currently occupied, where employees answered on a five-point Likert scale ranging from 1 strongly disagree to 5 strongly agree, and Who took the initiative for the last training course you concluded, where employees answered 1) I took the initiative myself; 2) My employer took the initiative; 3) We both took the initiative; and 4) Other. Employees' willingness to train is measured by the extent to which they agree with three propositions about their willingness to participate in 1) a course aimed at improving their skills for their current job, even when they have to sacrifice leisure time for this training; 2) a course aimed at improving skills needed to climb up in position in their organization; and 3) a training course aimed at learning skills needed for a new job. Employees

10. We also performed control analyses in which we used the underlying items of our training indicator and find that our main results hold for both items.

11. Research shows that personality traits (Fouarge et al., 2013) and job tasks (Görlitz and Tamm, 2012) are important determinants of willingness to train and actual training participation.

12. The exact wordings of these questions were: "Did you participate in the past year or are you currently participating in a training course? Please disregard hobby training courses." and "In how many training courses did you participate in the past year (including those in which you currently participate)?” 
answered these questions on a five-point Likert scale ranging from 1 strongly disagree to 5 strongly agree.

The survey questions on personal characteristics and personality include, among others, education level, marital status, job engagement and the "Big Five" personality traits: openness to experience, conscientiousness, extraversion, agreeableness, and neuroticism. ${ }^{13}$ The traits are derived from the abbreviated 15-item Big Five validated by Furnham et al. (2003) and McManus and Furnham (2006), which includes three items for each personality trait. We constructed the Big Five personality traits by taking the average score of the items belonging to each personality trait. Job engagement measures the extent to which employees are fully involved in, and enthusiastic about, their job, and is based on the short form of the Utrecht Work Engagement Scale (UWES), which has been used and validated extensively (see, e.g., Schaufeli et al., 2002).

Finally, we identify the various job tasks performed by employees by means of 18 questions from the Princeton Data Improvement Initiative (PDII), also used in Autor and Handel (2013).

\subsection{Descriptive statistics}

Table B2 of Appendix B presents the observable characteristics of employees in our sample. Employees in our estimation sample expect, on average, to retire at the age of 65 and two months. Figure 1, however, shows that there are strong peaks in retirement expectations that concentrate around the eligibility ages for the state old age pension. ${ }^{14}$ Approximately $28 \%$ expect to retire at age

13. The Big Five personality traits are five broad domains or dimensions of personality used in psychology to provide a comprehensive description of human personality; they are based on the Five Factor model (Goldberg, 1992). These Big Five personality traits are assumed to account for the basic traits in personality without overlap between traits.

14. The Dutch pension system consists of three pillars. The first consists of a flat-rate public scheme (AOW) to which all residents are entitled as of attainment of age 65 or 67 years, depending on year of birth, regardless of whether they are employee, self-employed or never participated in the labor market. This statutory old-age pension provides Dutch residents with a pension benefit that in principle guarantees $70 \%$ of the net minimum wage for a single household and $50 \%$ for each partner in a couple (either married or officially living together). The eligibility age will be stepwise increased from age 65 to 66 in 2018, and 
$65,13 \%$ at age 66 and $26 \%$ at age 67 . There is also a sizable group (28\%) of employees who expect to retire well before age 65 . Conversely, the group of workers who expect to continue working after the eligibly age for the state old age pension is relatively small (5\%).

Table B2 further shows that $61 \%$ of the employees in our sample participated in a training course in the past year. They, on average, participated in 1.41 training courses. Employees are most willing to train to improve their skills for their current job, while they are relatively unwilling to participate in a course aimed at improving their skills to climb to a higher position in their organization. Finally the table shows that $62 \%$ of our estimation sample is male, $84 \%$ is married, $23 \%$ is aged between 45 and 54 years, $69 \%$ is between 55 and 64 years old, and $72 \%$ of the employees are highly educated (higher vocational education or university degree), which reflects the fact that these workers are over-represented in the public sector. ${ }^{15}$

\subsection{Empirical strategy}

To identify and quantify the relationship between training access and expected retirement age, we use ordered probit regressions that take the following form:

$\operatorname{Pr}\left(Y_{i j}=k\right)=P R\left(v_{k-1}<\left(\alpha+\beta T A_{j}+\boldsymbol{\delta}^{\prime} \mathbf{X}_{i j}+\lambda^{\prime} V_{j}+e_{i j}\right) \leq v_{k}\right)$

where $Y_{i j}$ stands for the expected retirement age of individual $i$ in firm $j, T A_{j}$ represents the training access in firm $j, \mathbf{X}_{i j}$ is a vector of individual control variables, $\mathbf{V}_{j}$ is a vector of firm-specific control variables, and $\mathrm{e}_{\mathrm{i}}$ is the error term. $\mathbf{V}_{j}$ includes four indicators that measure the extent to which other

further up to 67 years in 2021. The second pillar refers to the supplementary earnings-related pension. This is a defined-benefit type of pension for employees organized at the sector or firm level. This pension can also be used to retire early, before the eligibility age for the state pension. The third pillar includes all voluntarily built-up savings that are in addition to the first two pillars. Due to the well-established first two pillars of the Dutch pension system, the third pillar is less developed in the Netherlands than in other countries.

15. Reassuringly, the proportion of highly educated workers in our sample is consistent with that in other datasets, such as the Dutch Labor Supply Panel. 
HR practices focusing on older workers are applied by the employer. $\mathbf{X}_{i j}$ includes employee age, education level, ${ }^{16}$ sector dummies, contractual working hours, wage, tenure, gender, marital status, personality characteristics, and job tasks of the individual employees. The coefficients $\alpha, \beta, \delta$ and $\lambda$, are to be estimated together with the cut-points $v_{1}, \ldots, v_{\mathrm{K}}$, where $\mathrm{K}$ represents the number of potential answers to the expected age of retirement question.

We use ordered probit regressions to address the fact that employee retirement expectations are concentrated at specific ages. Since there are multiple employee observations for a large number of organizations, we use a clustered sandwich estimator to allow for intragroup correlation on the organizational level (Rogers, 1993: Wooldridge, 2002). In a robustness analysis, we also estimate a hierarchical linear model with an additional random effect to account for unobserved heterogeneity on the organizational level.

\section{Results}

\subsection{Main results}

Table 1 presents the ordered probit estimation results of a base specification in which we relate the extent of training access in an organization to employee retirement expectations. We control for personal characteristics and the four other HR practices targeted toward older workers (Column 1). The estimation results show that employee expected age of retirement is positively related to the organization's training access provision: A one standard deviation increase in the extent of training access is associated with a 1.1-month higher expected retirement age. ${ }^{17,18,19}$ This relationship may

16. One education dummy that measures whether employees completed education at a lower level, and one education dummy that measures whether employees completed higher vocational education or achieved a university degree.

17. This effect is especially large among high-educated employees. The marginal effect for the interaction between the firm's training policy and the dummy for high education equals 0.203 (not shown in table).

18. Figure 2 shows the Kernel distribution of expected retirement ages for employees who work in organizations that provide above- and below-median training access. The figure suggests that the provision of training access shifts the whole distribution of the expected retirement age to the right.

19. We also performed the same analysis using the underlying items of our training access indicator. We find a significant coefficient of the item "extra education or training participation" of 0.103 with s.e. 0.046 , while 
appear to be small at first instance, but when we compare the size of this correlation to the impact of a major Dutch pension reform on expected retirement age, it becomes clear that training access is of great economic importance. De Grip et al. (2013) found that an announced increase in the Dutch statutory retirement age of one year increases expected retirement age by only 3.9 months. ${ }^{20}$

With respect to the four other HR practices targeted at older workers, we find no significant relationship with employee retirement age expectations. Table 1 further presents the results of analyses in which we subsequently add the Big Five personality traits (Column 2), along with 18 job task indicators (Column 3). These variables are added because employees' personalities and the tasks they perform on the job could confound the relationship between having training access and employee retirement expectations. ${ }^{21}$ The marginal effect of our training access indicator on expected retirement age hardly changes and remains statistically significant. We find that both conscientiousness and neuroticism are negatively related to expected retirement age. ${ }^{22}$

the coefficient of the item "training aimed at rethinking retirement and the professional career" is 0.035 with s.e. 0.025 .

20. Other studies, which focused on the effects of actual pension reforms, or used simulation studies, found similar results. Mastrobuoni (2009) found that a rise in the eligibility age for retirement in the U.S. by two months in 2003 postponed the actual retirement age only 1 month. Fields and Mitchell (1984) and Gustman and Steinmeier $(1985,2005)$ simulate that a rise in the eligibility age in the U.S. with two years leads to a two-month increase in the retirement age. Van Erp and De Hek (2009) simulated that a one-year increase in the eligibility age of the state old-age pension in the Netherlands leads to a one-month increase in the retirement age.

21. Previous studies have found a strong, direct relationship between job characteristics, such as high physical demands, repetitive working conditions, and early retirement (Filer and Petri, 1988). By controlling for the main job tasks, we reduce the likelihood that job characteristics, such as the time that employees perform tasks from which they can learn, which is likely to be positively correlated to training access and the expected retirement age, are driving our results.

22. Hurd et al. (2012) showed that conscientious people are better financially prepared for retirement, while Robinson et al. (2010) found that neurotic individuals more often report 'negative circumstantial motives' for retirement. 


\subsection{Why is there a positive impact from training policies on expected retirement age?}

The above-described results show that employees of organizations that provide more training access expect to retire later than those who work in organizations that do not provide training access to their employees. The question is what are the mechanisms behind this relationship? We will here test the relevance of two possible mechanisms. One explanation for the positive impact of training policies on expected retirement age may be that training access directly affects a worker's participation in training, while these human capital investments in turn influence employee labor productivity and wages, thereby increasing the opportunity costs of early retirement. However, employees may also perceive the provision of training access as an investment by their employer in the work relationship. It is therefore important to: 1) disentangle the role of training access from the influence of actual employee training participation, and 2) establish to what extent an employee's appreciation of their employer's training access policy induces them to positively respond by increasing their effort and/or retiring later (Barrett and O'Connell, 2001).

\subsubsection{Actual training participation}

Table 2 shows the results of a multinomial logistic regression where we relate training access for older workers offered by the firm to employees' actual participation in training. The dependent variable is based on the survey questions on whether the employee participated in a training course last year, who took the initiative for the training and the extent to which the skills learned were transferable to other employers. It is coded 0 when employees participated in no training course, 1 when employees received a firm-specific training course (employees replied with a score of 3 or below to the question on whether the knowledge is transferable) without any initiative from their employer, 2 when they participated in a firm-specific training course with support of their employer (either they report that their employer took the initiative or that both took the initiative), 3 when they received a general training course without the support of their employer (employees replied with a score of 4 or 5 to the question on whether the knowledge is transferable), and 4 when they received a general training course with support from the employer. 
The table shows that employees in organizations with strongly developed training policies indeed more often participate in general training courses with support from their employer, while access to training for older workers is not significantly related to worker participation in firm-specific training. A one-standard deviation increase in the training access indicator is associated with a $3.6 \%$ higher likelihood of participating in general training with support of the employer. Hence, it is possible that the positive relationship between training access and expected retirement age runs through the actual participation in general training.

We therefore re-estimate the specification in Column 3 of Table 1, in which we control for actual training participation and the number of training courses. From Table 2, we observe that the correlation between the training access indicator and expected retirement age is robust to the inclusion of individual training participation. ${ }^{23}$ Actual individual training incidence is not significantly related to the timing of retirement, which can be explained by the fact that the training decision is highly endogenous with respect to both the motivation and the job tasks of individual employees, which are already controlled for in the model. The correlation between number of training courses and expected retirement age is statistically significant, but small. One additional training course leads to a 0.7month higher expected retirement age.

\subsubsection{Positive reciprocity}

The above results thus suggest that providing training access to older workers within organizations may induce later retirement, beyond workers' actual training participation. A possible explanation for this finding is that the positive correlation between the organization's training policies and the individual expected retirement age is driven by employees' positive reciprocal inclinations. This conjecture is based on abundant evidence provided by experimentalists and psychologists, who showed that reciprocity is a key driver of human motivation and labor market outcomes (see, e.g.,

23. We also estimate the model including dummy variables, indicating the specific type of individual training participation (general or firm-specific with or without support of the employer). The results are robust to using these alternative measures. 
Akerlof, 1982; Bowles, 2008). In particular, Leuven et al. (2005) showed that positive reciprocal inclinations of employees are critical to explaining why employers are willing to provide firm-specific as well as general training to their employees. ${ }^{24}$ Their argument is that training positively affects the knowledge, skills and productivity of individual employees, who may therefore perceive the willingness of their employer to offer training opportunities and to pay for both firm-specific and general training as a gift, or as a signal of attention and recognition by the employer, for which they would like to positively reciprocate. Positive behavior by employers may thus increase the job motivation and engagement of positively reciprocal employees, who then may reciprocate the favorable action by their employer, by increasing their effort at work and postponing retirement. The postponement of retirement can be beneficial to employers, in particular when they experience labor shortages, as it allows them to reap the benefits of their investments in the human capital of their current employees for a longer period.

We test whether the positive correlation between organizations' training policies and employee expected retirement age is driven by employees' positive reciprocal inclinations. For this purpose, we use a measure of reciprocity based on the scale developed by Perugini et al. (2003), who performed comprehensive validation tests and assessed the predictive power of their reciprocity scale for the behavior of participants in ultimatum games in laboratory experiments conducted in the United Kingdom and Italy. The three items with the highest loadings in their principal components analysis for positive reciprocity are included in our data set. ${ }^{25}$ Respondents had to indicate how well they identified themselves with each of the following three statements: 1) If someone does me a favor, I am prepared to return it; 2) I go out of my way to help somebody who has been kind to me before; 3) I am ready to undergo personal costs to help somebody who helped me before. Participants responded on a five-point Likert scale ranging from 1 (does not apply to me at all) to 5 (applies perfectly to me). We

24. Among others, Pischke (2001) showed that, as opposed to what can be expected based on the standard human capital theory, workplace training is often of a general nature and is provided by employers at no direct cost for the employer.

25. These items were also included in the 2005 German Socio Economic Panel wave. The behavioral validity of these items is further investigated and confirmed by Dohmen et al. (2009) and Montizaan et al. (2012). 
first take the arithmetic average of a respondent's answers to these three questions, and compute the sample median value. Our measure of positive reciprocity equals 1 for respondents whose score is above the median, 0 otherwise. ${ }^{26}$

Table 4 shows the estimation results of an ordered probit regression with the interaction term between the positive reciprocity indicator and training access; this shows a statistically significant positive interaction effect between positive reciprocity and training access. ${ }^{27}$ Positive reciprocal employees within organizations with unlimited training access expect to retire 3 months later than positively reciprocal employees who work in organizations which do not offer any training opportunities to their older employees, and 1.5 months later than non-positive reciprocal employees who work in organizations with training access. This suggests that the positive relationship between training access and expected retirement age is indeed stronger for employees with strongly positively reciprocal inclinations. ${ }^{28}$

\subsection{Robustness}

While the results in Tables 1-4 highlight the importance of giving training access to older workers as a potential motivating stimulus for later retirement, the relevance of the finding may be limited

26. We also perform interaction analyses with the arithmetic average of a respondent's answers to the three reciprocity questions, and find similar results.

27. We find similar results when we use the underlying items of our training access indicator. We find a significant coefficient of the interaction term positive reciprocity and a dummy indicator which indicates whether employers provided "extra education or training participation" (coefficient 0.431 with s.e. 149), as well as a significant coefficient of the interaction with "training aimed at rethinking retirement and the professional career" (coefficient 0.450 with s.e. 0.161 ).

28. We also perform an ordered probit regression with the interaction term between the positive reciprocity indicator and training access on the quit intentions of the younger employees in our sample (employees below the median age in the sample). Quit intentions are measured by the survey question Are you presently searching for a new job, or did you search for a new job in the past year? Consistent with our estimations on expected retirement age, we find that positively reciprocal employees who work in organizations that provide training access are less likely to quit (coefficient of the interaction effect is 0.404 with s.e. 0.213 ). We do not find this result for older employees, which can be explained by the fact that the quit rate of this group is much lower. 
because of self-selection of highly educated and motivated employees into organizations with attractive training policy-practices, or by the fact that organizations' training policies are endogenous.

First, the estimation results could reflect self-selection of highly educated and motivated employees into organizations with attractive training policy-practices, leading to both a higher average retirement age and prevalence of training policies within these organizations. Column 1 of Table 5 shows ordered probit estimation results of the specification used in Column 3 of Table 1, in which several variables are added to control for the education level within firms and motivation of the employees. ${ }^{29}$ We here include the percentage of highly educated employees in the organization as reported by the employer, individual willingness to train, and job engagement. The latter two variables measure the extent to which employees are involved in and motivated for their work (Schaufeli et al., 2002). The inclusion of these control variables slightly reduces the marginal effect of the firm's training access indicator, but it remains statistically significant. As expected, we find that both employee willingness to train for their current job and their willingness to train for a new job are positively related to expected retirement age. The percentage of highly educated employees and the willingness to train to advance in the organization are, however, not statistically significantly correlated with the timing of retirement.

Second, one could conjecture that giving training access to the workforce and individual retirement expectations are simultaneously influenced by the productivity of the workforce within an organization. Bartel and Sicherman (1993) showed that retirement age and on-the-job training are positively correlated with exposure to gradual technical change and productivity growth. In the estimation in Column 2 of Table 5, we control for self-assessed individual productivity growth. This variable is based on the following question in the employee survey: Suppose your productivity equaled 100 one year ago. How would you then assess your productivity at this moment? Smaller

29. All additional control analyses were also performed on the model with the interaction term between positive reciprocity and training access as reported in Table 4. The significant interaction effect of training access and positive reciprocity on expected retirement age remains, even when we include all the control variables reported in Table 5. 
than 100 means less productive and larger than 100 means more productive. Further, since bad health often increases the likelihood of early retirement, we also include a self-assessed measure of employee health and the number of sick days in the past year. However, the negative correlation between training access offered by the firm and the expected retirement age of its employees remains unaffected when we include these individual productivity growth and health indicators.

Third, it could be that organizations that offer training access for older workers are able do so because of better financial conditions, the presence of a more active personnel department, or other unobserved organizational characteristics. To address these issues, we added several variables that measure the financial condition of the organization and that provide information on the overall HR management of the organization. Financial condition is measured by two questions in the employer survey: How would you describe the financial condition of your organization, with answer categories ranging from 1 Very bad to 5 Very good; and Has there been any reduction in the organizational workforce in the past year. The characteristics of general HR management of the organization are extensively measured by 11 indicators derived from a factor analysis on employers' answers to a list of 48 questions on the extent to which various HR practices are applied within the organization. ${ }^{30}$ Further, we estimate a hierarchical linear model with a random effect that accounts for unobserved heterogeneity at the organizational level. Columns 3-5 of Table 5 show that our results are robust to inclusion of these controls for financial conditions, overall HR management as well as time invariant unobserved characteristics of the organizations. ${ }^{31}$ The size of the marginal effect of offering training

30. Table B3 in Appendix B describes and shows descriptive statistics for these $11 \mathrm{HR}$ indicators.

31. Postponing retirement can be considered as a positive reciprocal action by the employee only when their employers are also willing to keep them to a higher age. We therefore separately estimate the ordered probit regression with the interaction terms between the positive reciprocity indicator and training access for employees who work in organizations that are financially sound or did not experience a reduction in their workforce in the past year, and those who are employed by organizations with financial difficulties or which had to reduce their workforce. Reassuringly, we find that the interaction effect between training access and positive reciprocity is large and statistically significant in the regressions for employees of organizations that are in good financial condition (coefficient 0.254 with s.e. 0.103 ) or did not experience a reduction in the workforce (coefficient 0.390 with s.e. 0.189), while there is no significant interaction 
access to older workers on expected retirement age increases slightly to 0.127 when we control for overall HR management of the organization and to 0.236 when the organization random effect is included. This suggests that organizations that offer training access to their older workforce have unobserved characteristics that induce early retirement, which leads to underestimation of the relationship between offering training access and expected retirement age.

Finally, we test whether our results are due to reverse causality. It is unlikely that reverse causality would play an important role in our previous estimations, due to the fact that we link training access reported by employers to the individual retirement expectations of the employees in our estimation sample. Nevertheless, it could be the case that the individual expected retirement age is higher due to the fact that employees in certain organizations retire, on average, later than in other organizations. In turn, we could then expect that organizations with a late average retirement age are more willing to design training policies for their older employees. We therefore conducted two tests to establish whether reverse causality biases our estimation results. For the first test, we use administrative data on actual retirement behavior of male public sector workers born in 1949 or 1950. ${ }^{32}$ The data were collected from the Dutch pension fund in 2013 for all male public sector employees in these two respective birth cohorts, with the advantage that the great majority of the men in this data set is already retired or currently retiring. For each organization, we calculate the percentage of employees who were born in 1950, the percentage of employees born in 1949 or 1950 who are currently retired, and their average retirement age. We subsequently match these organizational indicators on actual retirement behavior to our data set and add them as additional control variables in our estimations. In case of reverse causality, we would expect that the inclusion of

effect for employees of organizations with financial difficulties (coefficient 0.044 with s.e. 0.324) or which experienced a reduction of the workforce (coefficient 0.130 with s.e. 0.134 ). These results therefore suggest that positively reciprocal employees expect to retire later only when their employer is also more likely to be willing to keep them to a later age.

32. These data are part of a panel database used in other studies to measure the effects of a major pension reform in the Dutch public sector that occurred in 2006 (e.g., Montizaan et al., 2010; De Grip et al., 2012; Montizaan et al., 2012; and Montizaan and Vendrik, 2014). We do not have administrative information on actual retirement behavior for other birth cohorts. 
the organizational average retirement age of these cohorts should diminish the marginal effect of the training access indicator. The estimation results in Column 1 of Table 6 show that the coefficients of the percentage of a firm's employees born in 1949 and 1950 who are currently retired and the firm's average retirement age of these two cohorts have the right sign, but are statistically insignificant. More importantly, however, inclusion of these variables does not affect our conclusion on the relation between training access and expected retirement.

In the second test, we include the average expected retirement age of colleagues within the same organization as an additional control variable in our model. In our survey, 738 employees work in an organization in which more than one employee responded to the employee survey. These employees have a median number of four colleagues for whom we observe an expected retirement age. Again, in case of reverse causality, we would expect that the inclusion of the average expected retirement age of colleagues should diminish the marginal effect of the training access indicator. The estimation results in Column 2 of Table 6 show that the expected retirement age of workers is also not affected by the retirement expectations of their colleagues, and that inclusion of this variable does not affect the relationship between training access and expected retirement age. These two robustness checks suggest that the relationship between training access and expected age of retirement may be causal. ${ }^{33}$

33. We also estimated an instrumental variables (IV) model in which the existence of bonus payment schemes is used to instrument for the firm's training policy (results available on request). Bonus payment schemes provide monetary gift incentives, and may be a substitute for non-monetary gift incentives such as the provision of training access. This makes bonus payment a potentially suitable instrument for training provision by the firm. The first stage of the IV-estimation subsequently showed that the extent to which bonus payments are applied in organizations is indeed significantly negatively related to the degree that training policies are applied. In the second stage, we observe that training policies still have a significant positive effect on expected retirement age. These results further suggest that training policies may have a causal impact on retirement expectations. 


\section{Conclusion}

This paper investigates whether a firm's training access policy targeted at the older workforce can be successful in stimulating the employability and labor market attachment of older workers. For this purpose, we employ a unique, matched employer-employee data set that allows us to investigate whether policies providing organizational training targeted at older workers, as reported by employers, is related to the expected retirement age of their employees. The data set builds on two linked employer-employee surveys conducted in April 2012 in the Dutch public and privatized sector: an employer survey specifically designed to collect detailed information on organizations' HR practices, and that includes several measures of the extent to which training investments of older workers are stimulated by their employers, and an employee survey that elicits expected retirement age.

We find that offering training access to older employees is significantly positively related to the expected retirement age of a firm's workforce. A one-standard deviation increase in the degree to which employers offer training access is associated with an approximately 1.1-to-3.0-month higher expected retirement age. We show that this relationship is not likely to be driven by self-selection of highly educated and motivated employees in organizations with extensive training policies, higher labor productivity, better financial situation of the organization, overall HR management or reverse causality.

Moreover, the positive correlation between offering training access to older workers and expected retirement age is robust to controlling for employees' actual training participation. This suggests that access to training has positive effects on the timing of retirement over and beyond workers' actual training participation. We show that this positive correlation between generous training access and the expected retirement age of individual employees is strongly driven by employees' positive reciprocal inclinations, especially of employees who work in organizations that are financially sound and that did not reduce their workforces in the preceding year. Positively reciprocal employees employed in organizations that offer training access to older workers on average expect to retire 3 months later than positively reciprocal employees who work in organizations with 
no training access, and 1.5 months later than non-positively reciprocal employees of organizations that offer training access. This shows that provision of training access to older workers may not only improve the skills and productivity of employees, but also have major positive behavioral consequences that enable firms to reap the benefits of investments in the human capital of their workforce for a longer period.

By confirming that advanced organizational training policies can contribute to later retirement of specific groups of employees, these findings have great relevancy for public policies that aim to retain older workers in the labor market for a longer period. Our results strongly suggest that behavioral factors play a critical role in this relationship. The provision of training access may be a useful instrument that can complement pension system reforms that aim to increase the labor force participation rate of older workers as currently applied in many industrialized countries. Training access may further help to reduce the substantial negative effects of pension reforms on worker motivation and mental health documented by De Grip et al. (2012), Montizaan et al. (2012), and Montizaan and Vendrik (2014). The results underscore the need for further research on the complex relationship between organizational training policies and employee retirement behavior. 


\section{References}

Akerlof, G.A. (1982). "Labor contracts as partial gift exchange," Quarterly Journal of Economics, Vol. 97, 543-569.

Alessie, R.J.M., Van Rooij, M.C.J., and A. Lusardi (2011). "Financial literacy, retirement preparation and pension expectations in the Netherlands," NBER working paper 17109.

Autor, D., and M.J. Handel (2013). "Putting tasks to the test: Human capital, job tasks, and wages," Journal of Labor Economics, Vol. 31, S59-S96.

Barrett, A., and P.J. O'Connell (2001). "Does training generally work? The returns to in-company training," Industrial and Labor Relations Review, Vol. 54, 647-662.

Bartel, A.P. (1994). "Productivity gains from the implementation of employee training programs," Industrial Relations, Vol. 33, 411-425.

Bartel, A.P. (1995). "Training, wage growth, and job performance: Evidence from a company database,” Journal of Labor Economics, Vol. 13, 401-425.

Bartel, A.P., and N. Sicherman (1993). "Technological change and retirement decisions of older workers," Journal of Labor Economics, Vol. 11, 162-83.

Bassanini A., Booth, A., Brunello, G., De Paola, M., and E. Leuven (2005). "Workplace training in Europe," IZA working paper 1640.

Becker, G. (1962). "Investment in human capital: A theoretical analysis," Journal of Political Economy, Vol. 70: 9-49.

Bellemare, C., and B. Shearer (2009). "Gift giving and worker productivity: Evidence from a firmlevel experiment," Games and Economic Behavior, Vol. 67, 233-244.

Benitez-Silva, H., and D.S. Dwyer (2005). "The rationality of retirement expectations and the role of new information," The Review of Economics and Statistics, Vol. 87, 587-592.

Ben Porath, Y. 1967“The production of human capital and the life cycle of earnings," Journal of Political Economy, Vol. 75, 352-365.

Bishop, J. (1996). "What we know about employer-provided training: A review of the literature," Research in Labor Economics, Vol. 16, 19-87. 
Bowles, S. (2008). "Policies designed for self-interested citizens may undermine the moral sentiments," Science, Vol. 320, 1605-1609.

Brown, M., Falk, A., and E. Fehr (2004). "Relational contracts and the nature of market interactions," Econometrica, Vol. 72, 747-780.

Brunello, G., and S. Comi (2013). "The side effect of pension reforms on training: Evidence from Italy,” IZA discussion paper 7755.

Chan, C., and A.H. Stevens (2008). "What can't help you: Pension knowledge and retirement decision-making," The Review of Economics and Statistics, Vol. 90, 253-266.

Cohn, A., Fehr, E., and L. Goette (2009). "Fair Wages and Effort Provision: Combining Evidence from the Lab and the Field: Evidence from a field experiment," University of Zurich Working Paper No. 107.

Charness G. (2000). Responsibility and effort in an experimental labor market, Journal of Economic Behavior and Organization, Vol. 42, 375-384.

Conti, G. (2005). “Training, productivity, and wages in Italy," Labour Economics, Vol. 12, 557-576.

Das, M., Dominitz, J., and A. van Soest (1999). "Comparing predictions and outcomes: Theory and application to income changes. Journal of the American Statistical Association,” Vol. 94, 7585.

Daveri, F., and M. Maliranta (2006). "Age, seniority and labour costs: Lessons from the Finnish IT revolution," Economic Policy, Vol. 22, 117-175.

Dearden, L., Reed, H., and J. van Reenen (2006). "The impact of training on productivity and wages: Evidence from British panel data," Oxford Bulletin of Economics and Statistics, Vol. 68, 397421.

De Grip, A., Fouarge, D., and R. Montizaan (2013). "How sensitive are individual retirement expectations to raising the retirement age?" De Economist, Vol. 161, 225-251.

De Grip, A., Lindeboom, M., and R. Montizaan (2012). "Shattered dreams: The effects of changing the pension system late in the game,” The Economic Journal, Vol. 122, 1-25. 
De Grip, A., and J. van Loo (2002). "The economics of skills obsolescence: A review," in: A. de Grip, J. van Loo, and K. Mayhew (eds.), The economics of skills obsolescence: Theoretical innovations and empirical applications, vol. 21, Amsterdam: Elsevier-North Holland, 1-26.

De Grip, A., and J. Sauermann (2012). "The effects of training on own and co-worker productivity: evidence from a field experiment,” The Economic Journal, Vol. 122, 376-399.

Dohmen, T., Falk, A., Huffman, D., and U. Sunde (2009). "Homo reciprocans: Survey evidence on behavioral outcomes,” The Economic Journal, Vol. 119, 592-612.

Dominitz J. (2001). "Estimation of income expectations models using expectations and realizations data," Journal of Econometrics, Vol. 102, 165-195.

Dorn, D., and Sousa-Poza, A. (2010). “"voluntary' and 'involuntary' early retirement: An international analysis," Applied Economics, Vol. 42 (4), 427438.

Duflo, E., and E. Saez (2003). "The role of information and social interactions in retirement plan decisions: Evidence from a randomized experiment," Quarterly Journal of Economics, Vol. $118,815-842$.

Fehr, E., Kirchsteiger, G., and A. Riedl (1993). "Does fairness prevent market clearing? An experimental investigation,” Quarterly Journal of Economics, Vol. 108, 437-460.

Fehr, E., Kirchsteiger, G., and A. Riedl (1998). "Gift exchange and reciprocity in competitive experimental markets,” European Economic Review, Vol. 42, 1-34.

Fersterer, J., Pischke, J., and R. Winter-Ebmer (2008). "Returns to apprenticeship training in Austria: Evidence from failed firms," Scandinavian Journal of Economics, Vol. 110, 733-753.

Fields, G., and Mitchell, O. (1984). "Economic determinants of the optimal retirement age: An empirical investigation,” Journal of Human Resources, Vol. 19, 245-262.

Filer, R.K., and P.A. Petri (1988). "A job-characteristics theory of retirement," The Review of Economics and Statistics, Vol. 70, 123-128.

Fouarge, D. and Schils, T. (2009). "The effect of early retirement incentives on the training participation of older workers". Labour, Vol. 23, 85-109. 
Fouarge, D., Schils, T., and De Grip, A. (2013). "Why do low-educated workers invest less in further training?" Applied Economics, Vol. 45, 2587-2601.

Furnham, A., McManus, I.C., and D. Scott (2003). "Personality, empathy and attitudes to animal welfare," Anthrozoös, Vol. 16, 135-146.

Galasso, V., and Profeta, P. (2004). "Lessons for an ageing society: the political sustainability of social security systems," Economic Policy, Vol. 19, 63-115.

Gibbs, M., Merchant, K., Van der Stede, W., and M. Vargus (2009). "Performance measure properties and incentive system design," Industrial Relations, Vol. 48, 237-264.

Goldberg, L. (1992) "The development of markers for the Big-Five factor structure," Psychological Assessment, Vol. 4, 26-42.

Görlitz, K., and Tamm, M., 2012. "Revisiting the complementarity between education and training: The role of personality, working tasks and firm effects," IZA discussion paper 6278.

Green, F. (1993). "The determinants of training of male and female employees in Britain," Oxford Bulletin of Economics and Statistics, Vol. 55, 103-122.

Groot, W., and H. Maassen van den Brink (2000). "Education, training and employability," Applied Economics, Vol. 32, 573-581.

Gustman, A., and T. Steinmeier (1985). "The 1983 social security reforms and labor supply adjustments of older individuals in the long run," Journal of Labor Economics, Vol. 3, 237 253.

Gustman, A., and T. Steinmeier (2005). "The social security early retirement age in a structural model of retirement and wealth," Journal of Public Economics, Vol. 89, 441-463.

Hanushek, E., and L. Woessmann (2011). "How much do educational outcomes matter in OECD countries?”, Economic Policy, Vol. 26, 427-491, 07.

Herrbach, O., Mignonac, K., Vandenberghe, C., and A. Negrini (2009). "Perceived HRM practices, organizational commitment and voluntary early retirement among late-career managers," Human Resource Management, Vol. 48, 895-915. 
Hurd, M.D. (2009). "Subjective probabilities in household surveys, Annual Review of Economics," Vol. 1, 543-564.

Hurd, M.D., Duckworth, A., Rohwedder, S., and D. Weir (2012) "Personality traits and economic preparation for retirement,” Michigan Retirement Research Center, WP 2012-279.

Johnson, R. W., and Neumark, D. (1996). “Age discrimination, job separation, and employment status of older workers: Evidence from self-reports," Tech. Rep., NBER.

Katz, L.F., and D.H. Autor (1999). "Changes in the wage structure and wage inequality," in: O. Ashenfelter and D. Card (eds.), Handbook of labor economics, vol. 3A, Amsterdam: ElsevierNorth Holland, 1463-1555.

Keane, M., and D. Runkle (1990). "Testing the rationality of price forecasters: New evidence from panel data," American Economic Review, Vol. 80, 714-734.

Konings, J., and S. Vanormelingen (2009). "The impact of training on productivity and wages: Firm level evidence," CEPR discussion paper 7473.

Kube, S., Marchal, M., and C. Puppe (2012). "The currency of reciprocity-gift-exchange in the workplace,” American Economic Review, Vol. 102, 1644-1662.

Leuven, E., Oosterbeek, H., Sloof, R., and C. Van Klaveren (2005). "Worker reciprocity and employer investment in training" Economica, Vol. 72, 137-149.

Liebman, J.B., and E.F.P. Luttmer (2011). "Would people behave differently if they better understood social security? Evidence from a field experiment," NBER working paper 17287.

Mastrobuoni, G. (2009). "Labor supply effects of the recent social security benefit cuts: Empirical estimates using cohort discontinuities,” Journal of Public Economics, Vol. 93, 1224-1233.

McManus, I.C., and A. Furnham (2006) "Aesthetic activities and aesthetic attitudes: Influences of education, background and personality on interest and involvement in the arts," British Journal of Psychology, Vol. 97, 555-587.

Montizaan, R., Cörvers, F., and A. de Grip (2010). "The effects of pension rights and retirement age on training participation: Evidence from a natural experiment," Labour Economics, Vol. 17, 240-247. 
Montizaan, R., Cörvers, F., De Grip, A., and T. Dohmen, Thomas (2012). "Negative reciprocity and retrenched pension rights," IZA discussion paper 6955.

Montizaan, R., and M. Vendrik (2014). "Misery loves company: Exogenous shocks in retirement expectations and social comparison effects on subjective well-being," Journal of Economic Behavior \& Organization, Vol. 97, 1-26.

Neumann, S., and A. Weiss (1995). "On the effects of schooling vintage on experience-earnings profiles: Theory and evidence,” European Economic Review, Vol. 39, 943-955.

Pereira, P., Silva N., and J. Silva (2006). Positive and negative reciprocity in the labor market, Journal of Economic Behavior and Organization, Vol. 59, 406-422.

Perugini, M., Gallucci, M., Presaghi, F., and A.P. Ercolani (2003). "The personal norm of reciprocity," European Journal of Personality, Vol. 17, 251-283.

Picchio, M., and J. Van Ours (2013). "Retaining through training, even for older workers", Economics of Education Review, Vol. 32, 29-48.

Piscke, J. (2001). "Continuous Training in Germany", Journal of Population Economics, Vol. 14, 523548.

Robinson, O. C., Demetre, J. D., \& Corney, R. (2010). "Personality and retirement: Exploring the links between the Big Five personality traits, reasons for retirement and the experience of being retired". Personality and Individual Differences, Vol. 48, 792-797.

Rogers, W.H. (1993). "Regression standard errors in clustered samples," Stata Technical Bulletin, Vol. 13, 19-23.

Schaufeli, W.B., Salanova, M., Gonzalez-Roma, V., and A.B. Bakker (2002). "The measurement of engagement and burnout: A confirmative approach,” Journal of Happiness Studies, Vol. 3, 71-92.

Stenberg, A., De Luna, X., and O. Westerlund (2012). "Can adult education delay retirement from the labour market?" Journal of Population Economics, Vol. 25, 677-696.

Stephens Jr., M. (2004). “Job loss expectations, realizations and household consumption behaviour," The Review of Economics and Statistics, Vol. 86, 253-269. 
Van Erp, F., and P. de Hek (2009). "Analyzing labour supply of elderly people: A life-cycle approach," CPB memorandum 179.

Van Rooij, M.C.J., Lusardi, A., and R.J.M. Alessie (2011). "Financial literacy and retirement planning in the Netherlands," Journal of Economic Psychology, Vol. 32, 593-608.

Van Rooij, M.C.J., Lusardi, A., and R.J.M. Alessie (2012). Financial literacy, retirement planning and household wealth," The Economic Journal, Vol. 122, 449-478.

Wooldridge, J.M. (2002). Econometric analysis of cross section and panel data, Cambridge, MA: MIT Press.

Zwick, T. (2006). "The impact of training intensity on establishment productivity," Industrial Relations, Vol. 45, 26-46. 


\section{Figure 1}

\section{Retirement expectations}

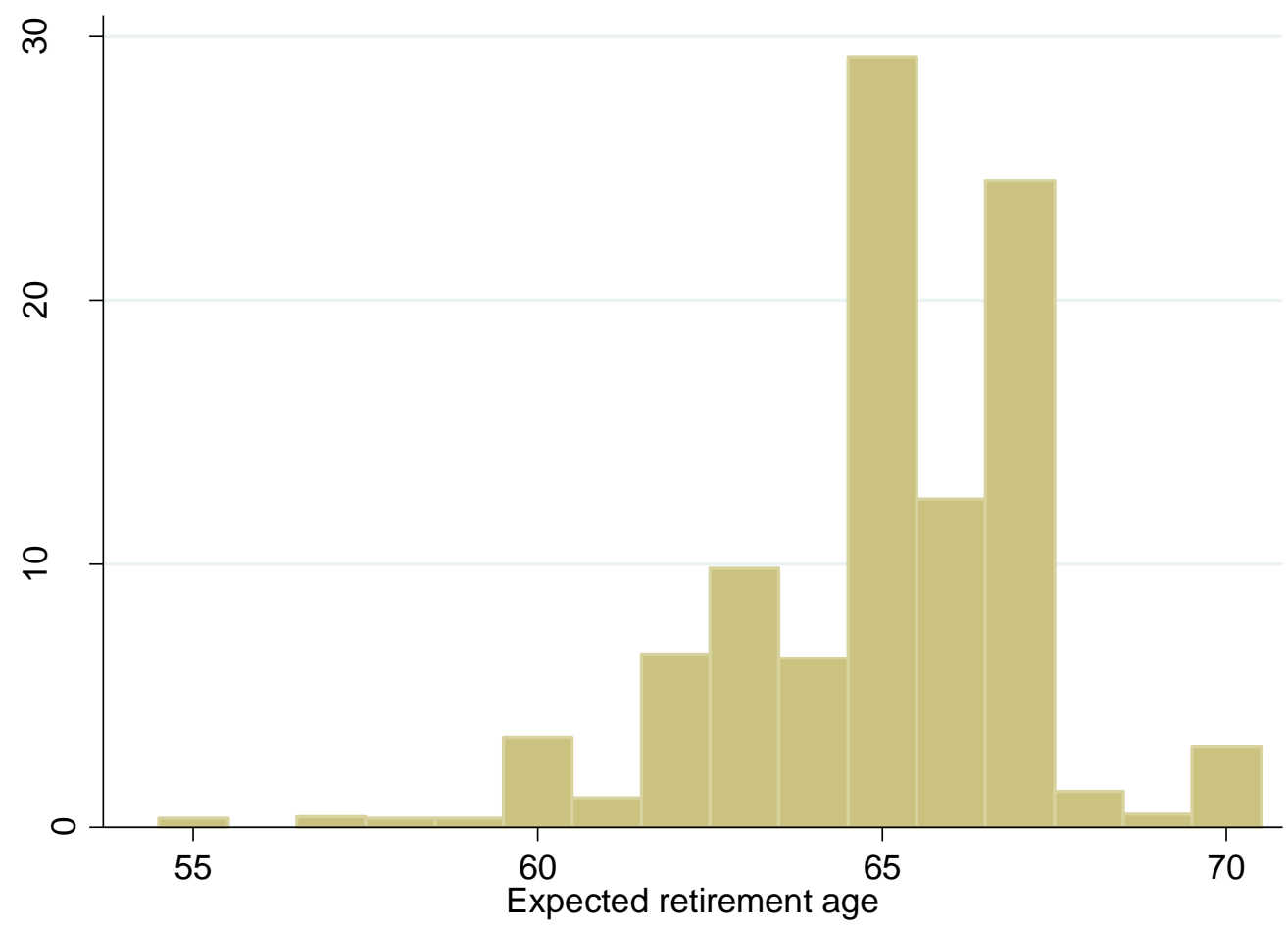


Figure 2

Retirement expectations of employees with and without training access (above / below median)*

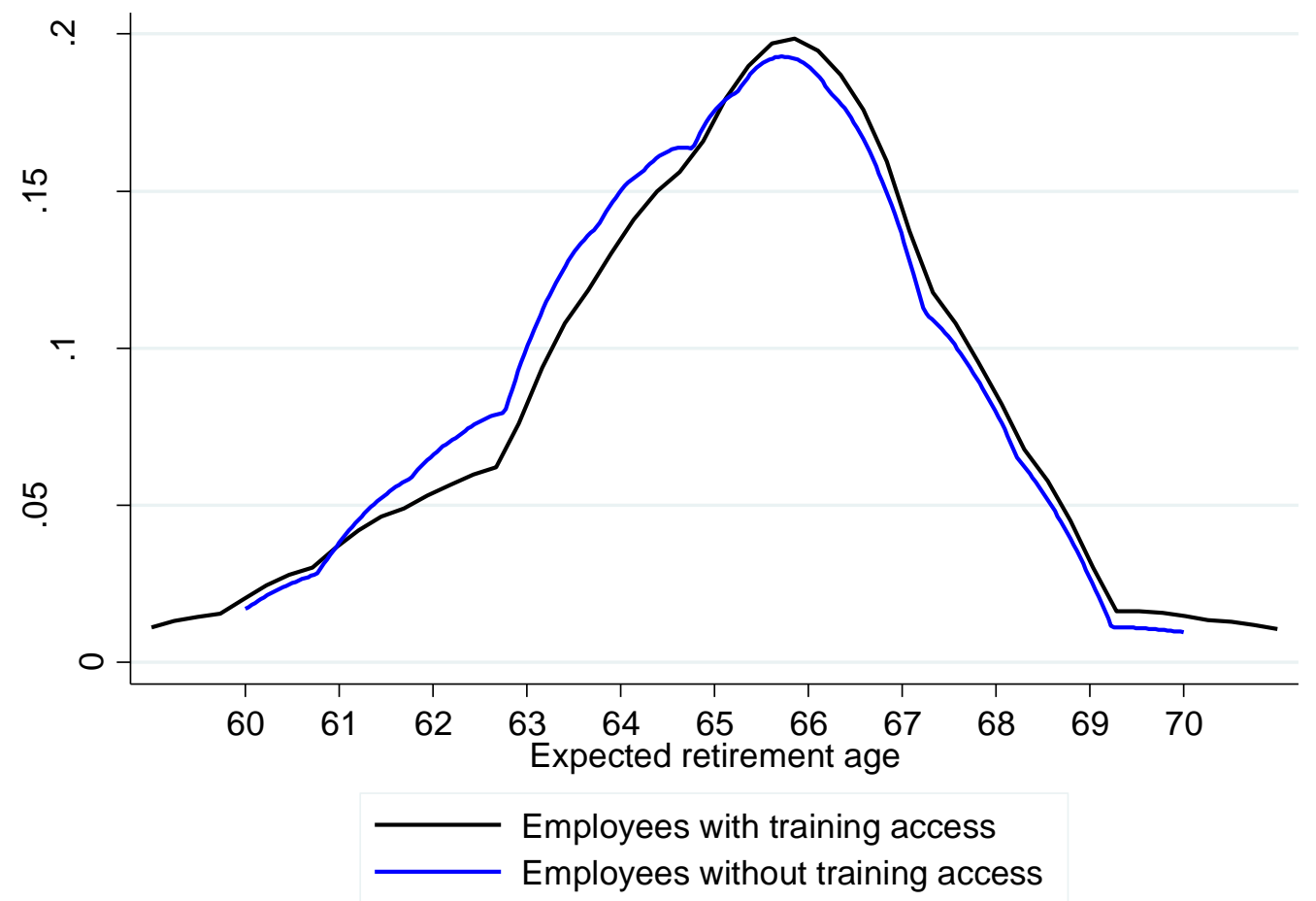

* Kernel density estimate (epanechnikov). 
Table 1

Employer-provided training access and expected retirement age

\begin{tabular}{|c|c|c|c|}
\hline Dependent variable: expected retirement age & (1) & $(2)$ & (3) \\
\hline \multicolumn{4}{|l|}{ HR practices focused on older workers } \\
\hline \multirow[t]{2}{*}{ Training access } & $0.091 * *$ & $0.090 * *$ & $0.092 * *$ \\
\hline & $(0.043)$ & $(0.041)$ & $(0.042)$ \\
\hline \multirow[t]{2}{*}{ Task adaptation } & -0.062 & -0.072 & -0.072 \\
\hline & $(0.045)$ & $(0.044)$ & $(0.046)$ \\
\hline \multirow[t]{2}{*}{ Financial incentives } & -0.021 & -0.018 & -0.014 \\
\hline & $(0.028)$ & $(0.028)$ & $(0.029)$ \\
\hline \multirow[t]{2}{*}{ Working hours policies } & 0.009 & 0.008 & -0.010 \\
\hline & $(0.056)$ & $(0.055)$ & $(0.055)$ \\
\hline \multirow[t]{2}{*}{ Retirement policies } & 0.004 & 0.008 & -0.003 \\
\hline & $(0.049)$ & $(0.049)$ & $(0.049)$ \\
\hline \multicolumn{4}{|l|}{ Personal characteristics } \\
\hline \multirow[t]{2}{*}{ Age $45-54$ (age $35-44$ is ref) } & -0.142 & -0.155 & -0.128 \\
\hline & $(0.163)$ & $(0.160)$ & $(0.163)$ \\
\hline \multirow[t]{2}{*}{ Age $55-64$} & $-0.492 * * *$ & $-0.494 * * *$ & $-0.464 * * *$ \\
\hline & $(0.147)$ & $(0.145)$ & $(0.141)$ \\
\hline \multirow{2}{*}{$\begin{array}{l}\text { Low education } \\
\text { (intermediate level of education is ref) }\end{array}$} & -0.120 & -0.156 & -0.038 \\
\hline & $(0.162)$ & $(0.161)$ & $(0.180)$ \\
\hline \multirow[t]{2}{*}{ High education } & 0.092 & 0.085 & 0.039 \\
\hline & $(0.102)$ & $(0.106)$ & $(0.113)$ \\
\hline \multirow[t]{2}{*}{ Government sector } & 0.079 & 0.052 & 0.069 \\
\hline & $(0.112)$ & $(0.108)$ & $(0.118)$ \\
\hline \multirow[t]{2}{*}{ Education sector } & $0.248^{*}$ & $0.224 *$ & 0.197 \\
\hline & $(0.130)$ & $(0.123)$ & $(0.131)$ \\
\hline \multirow[t]{2}{*}{ Wage (ln) } & -0.143 & $-0.232 *$ & $-0.359 * *$ \\
\hline & $(0.138)$ & $(0.131)$ & $(0.147)$ \\
\hline \multirow[t]{2}{*}{ Contractual working hours } & $0.648 * *$ & $0.685 * *$ & $0.767 * * *$ \\
\hline & $(0.273)$ & $(0.273)$ & $(0.289)$ \\
\hline \multirow[t]{2}{*}{ Tenure } & $-0.009 * * *$ & $-0.010 * * *$ & $-0.009 * * *$ \\
\hline & $(0.003)$ & $(0.003)$ & $(0.003)$ \\
\hline \multirow[t]{2}{*}{ Male } & 0.014 & 0.010 & -0.007 \\
\hline & $(0.091)$ & $(0.092)$ & $(0.094)$ \\
\hline \multirow[t]{2}{*}{ Married } & $-0.290 * * *$ & $-0.276 * * *$ & $-0.260 * * *$ \\
\hline & $(0.085)$ & $(0.087)$ & $(0.091)$ \\
\hline \multicolumn{4}{|l|}{ Personality traits } \\
\hline \multirow{2}{*}{ Neuroticism } & & $-0.103 * * *$ & $-0.112 * * *$ \\
\hline & & $(0.038)$ & $(0.040)$ \\
\hline \multirow[t]{2}{*}{ Extraversion } & & 0.039 & 0.032 \\
\hline & & $(0.057)$ & $(0.054)$ \\
\hline \multirow[t]{2}{*}{ Openness } & & 0.084 & 0.072 \\
\hline & & $(0.059)$ & $(0.059)$ \\
\hline \multirow[t]{2}{*}{ Agreeableness } & & -0.059 & -0.043 \\
\hline & & $(0.039)$ & $(0.038)$ \\
\hline Conscientiousness & & $-0.068 *$ & $-0.078 * *$ \\
\hline & & $(0.039)$ & $(0.038)$ \\
\hline Job tasks & No & No & Yes \\
\hline Observations & 845 & 845 & 845 \\
\hline
\end{tabular}

$* p<0.10, * * p<0.05, * * * p<0.01$. Standard errors (in parentheses) corrected for clustering on organization level. The table shows ordered probit estimates. The HR practices measures are derived from a factor analysis on employers' answers to 17 questions on HR practices focused on older workers. The Big Five personality traits are derived from the abbreviated 15-item Big Five validated by Furnham et al. (2003) and McManus and Furnham (2006). We use 18 variables to identify the job tasks performed by employees. These are based on 18 questions from the Princeton Data Improvement Initiative (PDII) Survey. The relevancy of these job task measures is validated by Autor and Handel (2013). 
Table 2

Employer-provided training access and employee training participation

\begin{tabular}{lccccc}
\hline & No training & $\begin{array}{c}\text { Specific } \\
\text { training } \\
\text { without } \\
\text { support }\end{array}$ & $\begin{array}{c}\text { Specific } \\
\text { training } \\
\text { with support }\end{array}$ & $\begin{array}{c}\text { General } \\
\text { training } \\
\text { without } \\
\text { support } \\
\text { (4) }\end{array}$ & $\begin{array}{c}\text { General } \\
\text { training } \\
\text { with support }\end{array}$ \\
\hline Training access & $(\mathbf{1})$ & $(\mathbf{2})$ & $\mathbf{( 3 )}$ & $\mathbf{( 5 )}$ \\
\hline Personal characteristics & -0.010 & 0.000 & -0.016 & -0.001 & $0.026^{* *}$ \\
Personality traits & $(0.022)$ & $(0.006)$ & $(0.019)$ & $(0.012)$ & $(0.012)$ \\
Job tasks & Yes & Yes & Yes & Yes & Yes \\
Observations & Yes & Yes & Yes & Yes & Yes \\
\hline
\end{tabular}

$* p<0.10, * * p<0.05, * * * p<0.01$. Standard errors (in parentheses) corrected for clustering on organization level. The table shows marginal effects of a multinomial logit on different types of training participation of individual employees with and without support by the employer, including all control variables of the specification presented in Column 3 of Table 1. 
Table 3

Employer-provided training access, actual training participation, and expected retirement age Dependent variable: Expected retirement age

Training access

(1)

0.085

(0.043)

Human capital investments

Training participation

Number of training courses

$0.057^{*}$

(0.027)

HR practices focused on older workers

Yes

Personal characteristics

Yes

Personality traits

Yes

Job tasks

Yes

Observations

844

$* p<0.10, * * p<0.05, * * * p<0.01$. Standard errors (in parentheses) corrected for clustering on organization level. The table shows ordered probit estimates, including all control variables of the specification presented in Column 3 of Table 1 . 
Table 4

Training access and expected retirement age: positive reciprocity

\begin{tabular}{lcc}
\hline Dependent variable: Expected retirement age & $(\mathbf{1})$ & $(\mathbf{2})$ \\
\hline Training access & $0.090^{* *}$ & 0.021 \\
& $(0.043)$ & $(0.053)$ \\
Positive reciprocity & 0.051 & -0.120 \\
& $(0.094)$ & $(0.100)$ \\
Training access x positive reciprocity & & $0.243^{* *}$ \\
& & $(0.100)$ \\
HR practices focused on older workers & Yes & Yes \\
Personal characteristics & Yes & Yes \\
Personality traits & Yes & Yes \\
Job tasks & Yes & Yes \\
Human capital investments & Yes & Yes \\
Observations & 834 & 834 \\
\hline
\end{tabular}

$* p<0.10, * * p<0.05, * * * p<0.01$. Standard errors (in parentheses) corrected for clustering on organization level. Column 1 of the table shows ordered probit estimates which include the same control variables as in Column 3 of Table 1 . 
Table 5

Alternative explanations: selection, productivity, financial condition of the organization and overall HR-management

\begin{tabular}{|c|c|c|c|c|c|}
\hline Dependent variable: Expected retirement age & (1) & $(2)$ & (3) & (4) & (5) \\
\hline Training access & $\begin{array}{l}0.083^{* *} \\
(0.040)\end{array}$ & $\begin{array}{l}0.095^{* *} \\
(0.040)\end{array}$ & $\begin{array}{l}0.090^{* *} \\
(0.041)\end{array}$ & $\begin{array}{l}0.127^{* *} \\
(0.053)\end{array}$ & $\begin{array}{l}0.236^{* *} \\
(0.105)\end{array}$ \\
\hline \multicolumn{6}{|l|}{ Characteristics of workforce } \\
\hline Percentage of highly educated workers & $\begin{array}{l}-0.002 \\
(0.002)\end{array}$ & $\begin{array}{l}-0.002 \\
(0.002)\end{array}$ & $\begin{array}{l}-0.002 \\
(0.002)\end{array}$ & $\begin{array}{l}-0.003 \\
(0.002)\end{array}$ & $\begin{array}{l}-0.006 \\
(0.005)\end{array}$ \\
\hline $\begin{array}{l}\text { Prepared to participate in a course aimed at improving } \\
\text { skills for current job }\end{array}$ & $0.095^{* *}$ & $0.105^{* *}$ & $0.107^{* *}$ & $0.079^{*}$ & $(0.097)$ \\
\hline $\begin{array}{l}\text { Prepared to participate in a course aimed at improving } \\
\text { skills needed to advance in the organization }\end{array}$ & $(0.043)$ & $(0.046)$ & 0.042 & 0.061 & 0.106 \\
\hline $\begin{array}{l}\text { Prepared to participate in a course aimed at learning } \\
\text { skills needed for a new job }\end{array}$ & $(0.050)$ & $(0.053)$ & $0.104^{*}$ & $(0.058)$ & $\begin{array}{c}0.057 \\
(0.118)\end{array}$ \\
\hline Job engagement & $\begin{array}{c}0.040 \\
(0.031)\end{array}$ & $\begin{array}{c}0.034 \\
(0.033)\end{array}$ & $\begin{array}{c}0.033 \\
(0.033)\end{array}$ & $\begin{array}{c}0.016 \\
(0.038)\end{array}$ & $\begin{array}{c}0.013 \\
(0.079)\end{array}$ \\
\hline Productivity indicators & & & & & \\
\hline Increase of productivity (self-assessed) & & $\begin{array}{l}-0.000 \\
(0.000)\end{array}$ & $\begin{array}{l}-0.000 \\
(0.000)\end{array}$ & $\begin{array}{l}-0.000 \\
(0.000)\end{array}$ & $\begin{array}{l}-0.000 \\
(0.000)\end{array}$ \\
\hline Bad health (self-assessed) & & $\begin{array}{l}-0.073 \\
(0.066)\end{array}$ & $\begin{array}{l}-0.077 \\
(0.066)\end{array}$ & $\begin{array}{l}-0.121^{*} \\
(0.071)\end{array}$ & $\begin{array}{l}-0.219 \\
(0.149)\end{array}$ \\
\hline Number of sick days (self-assessed) & & $\begin{array}{l}-0.001 \\
(0.002)\end{array}$ & $\begin{array}{l}-0.001 \\
(0.002)\end{array}$ & $\begin{array}{c}0.000 \\
(0.002)\end{array}$ & $\begin{array}{l}-0.001 \\
(0.005)\end{array}$ \\
\hline Financial condition of organization & & & & & \\
\hline Financial condition & & & $\begin{array}{c}0.040 \\
(0.050)\end{array}$ & $\begin{array}{c}0.084 \\
(0.064)\end{array}$ & $\begin{array}{c}0.187 \\
(0.128)\end{array}$ \\
\hline $\begin{array}{l}\text { Likelihood that organization has to cut expenses in } \\
\text { coming five years }\end{array}$ & & & $\begin{array}{c}0.046 \\
(0.054)\end{array}$ & $\begin{array}{c}0.047 \\
(0.066)\end{array}$ & $\begin{array}{c}0.127 \\
(0.133)\end{array}$ \\
\hline Personal characteristics & Yes & Yes & Yes & Yes & Yes \\
\hline Personality traits & Yes & Yes & Yes & Yes & Yes \\
\hline Job tasks & Yes & Yes & Yes & Yes & Yes \\
\hline Human capital investments & Yes & Yes & Yes & Yes & Yes \\
\hline Overall HR management & No & No & No & Yes & Yes \\
\hline Organization random effects & No & No & No & No & Yes \\
\hline Observations & 838 & 807 & 807 & 677 & 677 \\
\hline
\end{tabular}

$* p<0.10, * * p<0.05, * * * p<0.01$. Standard errors (in parentheses) corrected for clustering on organization level. Columns 1-4 show ordered probit estimates with the same control variables as in Column 3 of Table 1. Column 5 shows the results of a hierarchical linear model with random effects. The HR practices measures are derived from a factor analysis on employers' answers to 17 questions on the use of HR practices that are focused on older workers. The Big Five personality traits are derived from the abbreviated 15-item Big Five validated by Furnham et al. (2003) and McManus and Furnham (2006). Job tasks are measured using 18 questions from the Princeton Data Improvement Initiative (PDII) Survey. The relevancy of these job task measures are validated by Autor and Handel (2013). Overall personnel management is measured by 11 indicators derived from a factor analysis on employers' answers to 48 questions on the extent to which HR-instruments are applied within the firm. 
Table 6

Training access and expected retirement age: controlled for organizational retirement patterns

Dependent variable: Expected retirement age

Training access

Mean retirement age of 1949/1950 cohorts who were employed in the organization

Percentage of retirees of 1949/1950 cohorts in the organization

Percentage of employees born in 1950 in the organization's workforce

Mean expected retirement age of colleagues

HR practices focused on older workers

Personal characteristics

Personality traits

Job tasks

Human capital investments

Observations

0.01 . Standard errors (in parentheses) corrected for clustering on organization level. Columns 1 and 2 show ordered probit estimates, which include the same control variables as Column 3 of Table 1.

$\begin{array}{cc}\mathbf{( 1 )} & (\mathbf{2}) \\ 0.126^{\text {**** }} & 0.096^{* *} \\ (0.043) & (0.046) \\ 0.038 & \\ & \\ (0.048) & \\ -0.094 & \\ (0.226) & \\ 0.022 & \end{array}$

(0.239)

$-0.016$

$(0.042)$

Yes Yes

Yes $\quad$ Yes

Yes Yes

Yes Yes

Yes $\quad$ Yes

738

Yes

Yes 


\section{Appendix A}

\section{Table A1}

Employer survey questions on HR practices focused on older workers Employer survey questions on HR practices focused on older workers

To what extent does your organization apply the following HR instruments specifically targeted toward older employees?

1) Adaptation of the workplace

2) Giving tasks in which they perform relatively well

3) Task relief

4) Extra education or training participation

5) Training aimed at rethinking retirement and the professional career

6) Mentor function for older employees

7) Old age holiday days

8) Senior leave

9) Demotion

10) Wage decrease

11) Promotion

12) Shortening of labor hours

13) Part-time retirement

14) Extra investment in life course savings plans

15) Allowing employees to continue working after age 65

16) Wage guarantee

17) Departure schemes

Scale

Five-point Likert scale ranging from 1 "Applied to no older employee" to 5 "Applied to all older employees." 


\section{Appendix B}

Table B1 in Appendix B displays information on the distribution of employees over the various subsectors in the representative sample (Columns 1 and 2), the response rates to the employee survey (Column 3), the distribution of workers over subsectors in the employee survey (Columns 4 and 5) and the distribution of employees over sectors in the matched employer-employee data (Columns 6 and 7). The largest subsectors in the representative sample of public sector employees are Primary and Secondary Education (25.8\%), Municipalities (19.8\%) and the National Government (13.4\%). Column 3 shows that the response rates to the employee survey are very similar across sectors, at approximately $11 \%$. The lowest response rate is found for academic hospitals $(8.2 \%)$, while the highest response rate is found for workers in intermediate vocational education (12.8\%).

The representativeness of the estimation sample is further explored in Table B2, which presents the observable characteristics of employees with and without a match to their employer in Columns 1 and 2, respectively. Column 3 shows the t-statistic for the test of whether employee characteristics differ between employees with or without a match to their employer. We find that the between-group differences are small. There are only weakly significant differences (at the $10 \%$ level) in the number of 45-55 year-olds and highly educated, and in job engagement between the groups of employees with or without a match. Therefore, we can reasonably conclude that employees who can be matched to their employer are similar to those for whom no match is available. 
Table B1

Employee response rates by subsector

\begin{tabular}{|c|c|c|c|c|c|c|c|}
\hline \multirow[b]{2}{*}{ Sector } & \multicolumn{2}{|c|}{$\begin{array}{l}\text { Representative } \\
\text { sample }\end{array}$} & \multirow{2}{*}{$\begin{array}{c}\text { Response } \\
\text { rate } \\
\text { employee } \\
\text { survey } \\
\% \\
\text { (3) }\end{array}$} & \multicolumn{2}{|c|}{$\begin{array}{c}\text { Distribution of } \\
\text { workers in employee } \\
\text { survey }\end{array}$} & \multicolumn{2}{|c|}{$\begin{array}{c}\text { Distribution of } \\
\text { workers in employee } \\
\text { survey after match } \\
\text { with employer data }\end{array}$} \\
\hline & $\begin{array}{c}\text { Total } \\
\text { (1) }\end{array}$ & $\begin{array}{l}\% \\
(2)\end{array}$ & & $\begin{array}{c}\text { Total } \\
\text { (4) }\end{array}$ & $\begin{array}{l}\% \\
(5)\end{array}$ & $\begin{array}{c}\text { Total } \\
\text { (6) }\end{array}$ & $\begin{array}{l}\% \\
(7)\end{array}$ \\
\hline National government & 7,699 & 13.4 & 11.8 & 911 & 14.7 & 314 & 23.5 \\
\hline Defense (civilian personnel) & 2,322 & 4.1 & 10.3 & 240 & 3.9 & NA & NA \\
\hline $\begin{array}{l}\text { Provinces and district water } \\
\text { boards }\end{array}$ & 1,923 & 3.4 & 10.8 & 208 & 3.4 & 25 & 1.9 \\
\hline Municipalities & 11,340 & 19.8 & 10.2 & 1157 & 18.7 & 297 & 22.2 \\
\hline Police & 2,903 & 5.1 & 10.8 & 313 & 5.1 & 31 & 2.3 \\
\hline $\begin{array}{l}\text { Primary and secondary } \\
\text { education }\end{array}$ & 14,772 & 25.8 & 10.9 & 1610 & 26.1 & 374 & 28 \\
\hline $\begin{array}{l}\text { Intermediate vocational } \\
\text { education }\end{array}$ & 3,331 & 5.8 & 12.8 & 428 & 6.9 & 50 & 3.7 \\
\hline Higher vocational education & 2,259 & 3.9 & 11.8 & 267 & 4.3 & 71 & 5.3 \\
\hline Universities & 2,695 & 4.7 & 10.5 & 282 & 4.6 & 75 & 5.6 \\
\hline Academic hospitals & 2,723 & 4.8 & 8.2 & 223 & 3.6 & NA & NA \\
\hline $\begin{array}{l}\text { Water, energy and public } \\
\text { utilities }\end{array}$ & 2,442 & 4.3 & 10.7 & 261 & 4.2 & 26 & 1.9 \\
\hline Voluntary members & 1,992 & 3.5 & 9.7 & 194 & 3.1 & 46 & 3.4 \\
\hline \multirow[t]{2}{*}{ Other } & 949 & 1.7 & 9.0 & 85 & 1.4 & 28 & 2 \\
\hline & 57,350 & 100 & 10.8 & 6,179 & 100 & 1,337 & 100 \\
\hline
\end{tabular}


Table B2

Employee characteristics with and without a match to the employer

\begin{tabular}{|c|c|c|c|}
\hline & $\begin{array}{c}\text { Average } \\
\text { employees with } \\
\text { a match } \\
\end{array}$ & $\begin{array}{c}\text { Average } \\
\text { employees } \\
\text { without a match } \\
\end{array}$ & $\begin{array}{c}\text { t-stat } \\
\text { difference }\end{array}$ \\
\hline Expected retirement age & 65.13 & 65.01 & 1.45 \\
\hline Average score on positive reciprocity & 3.98 & 3.99 & 0.79 \\
\hline Age $45-54$ (age $35-44$ is ref) & 0.23 & 0.21 & $1.69 *$ \\
\hline Age 55-64 & 0.69 & 0.71 & 1.17 \\
\hline Low education & 0.05 & 0.04 & 0.34 \\
\hline High education & 0.72 & 0.70 & $1.90 *$ \\
\hline Wage $(\ln )$ & 10.9 & 10.9 & 0.52 \\
\hline Contractual working hours & 0.89 & 0.89 & 1.28 \\
\hline Tenure & 12.9 & 13.2 & 0.82 \\
\hline Male & 0.62 & 0.62 & 0.23 \\
\hline Married & 0.84 & 0.83 & 0.69 \\
\hline Training participation & 0.61 & 0.60 & 0.94 \\
\hline Number of training courses & 1.41 & 1.32 & 1.32 \\
\hline $\begin{array}{l}\text { Prepared to participate in a course aimed at } \\
\text { improving skills for the present job }\end{array}$ & 3.70 & 3.67 & 1.17 \\
\hline $\begin{array}{l}\text { Prepared to participate in a course aimed at } \\
\text { improving skills needed to climb up in position in } \\
\text { their organization }\end{array}$ & 3.00 & 3.01 & 0.32 \\
\hline $\begin{array}{l}\text { Prepared to participate in a course aimed at } \\
\text { learning skills needed for a new job }\end{array}$ & 3.43 & 3.44 & 0.18 \\
\hline Job engagement & 3.03 & 3.18 & $1.85 *$ \\
\hline Increase of productivity (self-assessed) & 110.9 & 103.3 & 1.10 \\
\hline Bad health (self-assessed) & 1.92 & 1.95 & 0.96 \\
\hline Number of sick days (self-assessed) & 6.3 & 6.7 & 0.56 \\
\hline
\end{tabular}

$* p<0.10, * * p<0.05, * * * p<0.01$. We also performed the same test on the 18 job task indicators used in Table 1 and found no significant differences in the job tasks of employees with and without a match to the employer data. 
Table B3

Organizational characteristics with and without a match to employee

t-stat difference in means

HR practices focused on older workers (standardized)

Training access

Task adaptation

Financial incentives

Working hours policies

Retirement policies

Other organizational characteristics

Percentage of highly educated workers

Financial condition

$12.7 * * *$

Likelihood that the organization must reduce

expenses in the coming five years

$10.2 * * *$

Overall HR management (standardized)

Overwork and shift work $\quad 1.54$

Flexible work hours $\quad 1.42$

Lifestyle and health investments $\quad 0.83$

Career advice and coaching $\quad 1.46$

Stimulating competences and working as an $\quad 1.08$

independent 1.08

Vitality and working conditions $\quad 0.81$

Demotion and promotion $\quad 0.28$

Communication and assessment $\quad 0.83$

Internal and external mobility $\quad 0.52$

Bonus payments and gratifications $\quad 0.16$

Sabbatical leave and employee saving schemes $\quad 0.05$

$* p<0.10, * * p<0.05, * * * p<0.01$. 